\title{
The Application of a Surface Response Methodology in the Solar/UV-Induced Degradation of Dairy Wastewater Using Immobilized ZnO as a Semiconductor
}

\author{
Gisella R. Lamas Samanamud, ${ }^{1,2}$ Helcio J. Izario Filho, ${ }^{1}$ Carla C. A. Loures, ${ }^{1,3}$ \\ Ivy S. Oliveira, ${ }^{1}$ Andre L. Souza, ${ }^{1}$ Ana Paula B. R. de Freitas, ${ }^{1,3}$ and Ruoting Pei ${ }^{2}$ \\ ${ }^{1}$ Department of Chemical Engineering, Engineering School of Lorena, University of Sao Paulo (USP), \\ Estrada Municipal do Campinho, s/n ${ }^{\circ}$, Bairro do Campinho, 126020-810 Lorena, SP, Brazil \\ ${ }^{2}$ Department of Civil and Environmental Engineering, University of Texas at San Antonio (UTSA), \\ One UTSA Circle, San Antonio, TX 78249, USA \\ ${ }^{3}$ Departament of Production Engineering, Sao Paulo State University (UNESP), 12516-410 Guaratingueta, SP, Brazil
}

Correspondence should be addressed to Gisella R. Lamas Samanamud; zeldals@hotmail.com

Received 30 May 2013; Accepted 15 August 2013

Academic Editor: Antonia Pérez de los Ríos

Copyright ( 2013 Gisella R. Lamas Samanamud et al. This is an open access article distributed under the Creative Commons Attribution License, which permits unrestricted use, distribution, and reproduction in any medium, provided the original work is properly cited.

\begin{abstract}
An Advanced Oxidation Process (AOPs) was carried out in this study with the use of immobilized $\mathrm{ZnO}$ and solar/UV as an energy source to degrade dairy wastewater. The semibatch reactor system consisted of metal plate of $800 \times 250 \mathrm{~mm}$ and a glass tank. The reaction time was of $3 \mathrm{~h}$ for $3 \mathrm{~L}$ of dairy wastewater. Experiments were performed based on a surface response methodology in order to optimize the photocatalytic process. Degradation was measured in percentage terms by total organic carbon (TOC). The entry variables were $\mathrm{ZnO}$ coating thickness and $\mathrm{pH}$, using three levels of each variable. The optimized results showed a TOC degradation of $31.7 \%$. Optimal parameters were metal-plate coating of $100 \mu \mathrm{m}$ of $\mathrm{ZnO}$ and $\mathrm{pH}$ of 8.0. Since solar/UV is a constant and free energy source in most tropical countries, this process tends to suggest an interesting contribution in dairy wastewater treatment, especially as a pretreatment and the optimal conditions to guarantee a better efficiency of the process.
\end{abstract}

\section{Introduction}

The use of $\mathrm{ZnO}$ as a semiconductor was studied for possible application in a photo-excitation-initiated degradation of the catalyst followed by the formation of a surface bandgap (see (1)). The oxidation potential $\left(\mathrm{h}_{\mathrm{VB}}{ }^{+}\right)$permits the formation of active intermediates by the direct oxidation of an organic matter (see (2)). Many reactive hydroxyl radicals can be formed either by decomposition of water or by a bandgap reaction with $\mathrm{OH}^{-}$(see (3) and (4)). The Hydroxyl radical is a powerful nonselective oxidation agent leading to organic pollutants degradation [1-3]. Consider that

$$
\mathrm{ZnO}+h \nu \longrightarrow \mathrm{ZnO}\left(\mathrm{e}_{\mathrm{CB}}{ }^{-}+\mathrm{h}_{\mathrm{VB}}{ }^{+}\right)
$$

$$
\begin{aligned}
\mathrm{h}_{\mathrm{VB}}{ }^{+}+\text {organic matter } \\
- \\
\longrightarrow \text { oxidation products (intermediates) } \\
\mathrm{h}_{\mathrm{VB}}^{+}+\mathrm{H}_{2} \mathrm{O} \longrightarrow \mathrm{H}^{+}+{ }^{\circ} \mathrm{OH} \\
\mathrm{h}_{\mathrm{VB}}{ }^{+}+\mathrm{OH}^{-} \longrightarrow{ }^{\circ} \mathrm{OH}
\end{aligned}
$$

The methodologies used in the design of experiments allow a similar result as the one obtained from conventional experiments with the advantage of the use of fewer experiments. Thus, a good design of experiments can provide sufficient results for an effective statistical analysis [4]. In order to obtain the optimized variables for the study of 


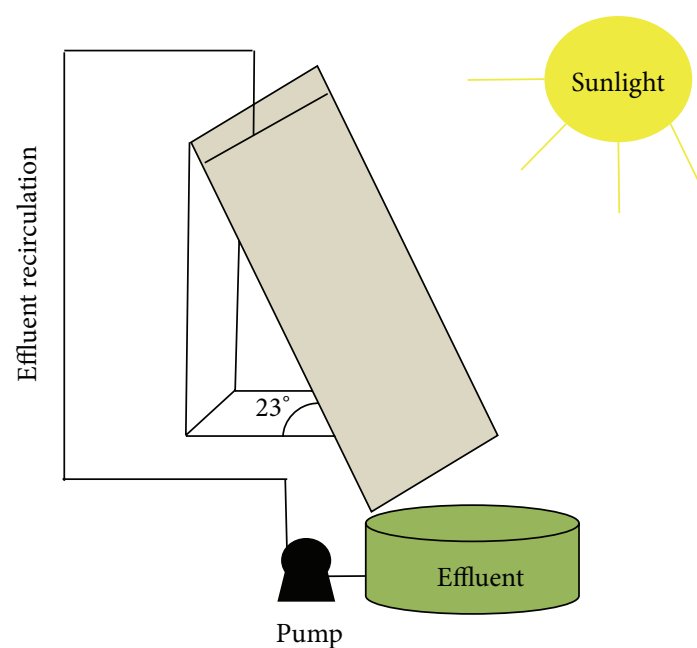

FIGURE 1: Schematic diagram of the solar reactor with $\mathrm{ZnO}$ photocatalyst based on [8].

dairy wastewater photocatalytic treatment, a surface response methodology was employed.

Dairy wastewater does not generally contain inherently toxic chemical substances, but it is composed of dissolved organic compounds that are not easily degradable by biological treatment without a prior treatment. In fact, this limitation affects the efficiency of the treatment through $\mathrm{pH}$ (depending on the type of dairy), overload of the system, and sludge volume. Moreover, dairy wastewater also produces an unpleasant odor and consists of a liquid with a significant color if the organic load is high enough [5-7].

\section{Materials and Methodology}

2.1. Sampling and Conservation. The dairy wastewater samples used in this work were generously provided by Cooperativa de Laticinios de Guaratingueta, state of Sao Paulo, and refrigerated at $4^{\circ} \mathrm{C}$ while stored.

\subsection{Preparation of the $\mathrm{ZnO}$ Coating and Experiment Proce-} dures. The immobilization of $\mathrm{ZnO}$ particles was carried out by the application of a coating containing the photocatalyst [8] by DuPont do Brasil S.A., in Guarulhos, Sao Paulo. Two identical $800 \times 250 \mathrm{~mm}$ stainless steel plates with an area of $200 \mathrm{~cm}^{2}$ were used each with a different thickness (50 and $100 \mu \mathrm{m})$. The coating containing $\mathrm{ZnO}$ was diluted until obtaining a sliding viscosity as described in [8]. Difference in thickness was obtained by applying an extra layer of the prepared $\mathrm{ZnO}$ paint to the $100 \mu \mathrm{m}$ plate.

The entire system was placed in a wooden structure that positioned the metal plate at $23^{\circ}$ in relation to the Earth's equatorial plane (Figure 1).

This angular position corresponds to the $23^{\circ}$ south latitude in order to enhance irradiation. The solar reactor was then placed to receive the solar UV responsible for the photoexcitation of $\mathrm{ZnO}$ particles. Solar/UV was monitored
TABLE 1: Variables and levels based on the Surface response methodology (15 runs with replication) for the dairy wastewater photocatalytic process.

\begin{tabular}{lccc}
\hline Control variables & Level -1 & Level 0 & Level 1 \\
\hline $\mathrm{pH}$ & 6.0 & 8.0 & 10.0 \\
$\mathrm{ZnO}$ coating thickness $(\mu \mathrm{m})$ & 0 & 50 & 100 \\
\hline
\end{tabular}

by Radiometer ILT1400-A. Figure 2 shows the scheme of UVinduced degradation, when a semiconductor as $\mathrm{ZnO}$ is used.

The preparation of samples was carried out according to the surface response methodology designed for this study, and experiments were conducted as in [10] without the blank procedure.

2.3. Surface Response Methodology for the Dairy Wastewater of This Study. A design was developed using a surface response methodology with a central point as shown in Table 1. Response was measured in TOC percentage terms. Experiments were conducted in pairs at the same time except those with central levels that were conducted one at a time. The advantage of using a surface response methodology is that it is able to analyze three levels instead of two as it happens to other designs of experiments. The surface response methodology consisted of 2 factors in duplicate with the base run of 15 , a total of 30 experiments.

2.4. Surface Response Matrix Procedure. According to Table 1 for the central point, sample was adjusted to $\mathrm{pH} 8.0$ with the addition of $\mathrm{NaOH} 5 \mathrm{~mol} \cdot \mathrm{L}^{-1}$. A metal plate with $\mathrm{ZnO}$ coating thickness of $50 \mu \mathrm{m}$ was used in the solar reactor. The first sample was collected before the beginning of the experiment. The last sample was collected after $3 \mathrm{~h}$. pH control was constant either by addition of $\mathrm{H}_{2} \mathrm{SO}_{4}$ or $\mathrm{NaOH}$. The procedure for the other experiments was analogous to the one described previously and performed randomly to guarantee the statistical significance of the experiments and avoid any bias. The efficiency of the process was evaluated in terms of TOC effective percentage degradation. TOC determinations were carried out in a Shimadzu Model TOC-VCPH analyzer using catalytic oxidation in high temperatures and $\mathrm{CO}_{2}$ determination by infrared spectroscopy.

\section{Results and Discussion}

3.1. Characterization of the Dairy Wastewater. Table 2 shows the physical-chemical results obtained for the dairy wastewater before and after the photocatalytic process using immobilized $\mathrm{ZnO}$ and Solar/UV.

BOD, chloride, phosphorous, ammonia, TOC, and turbidity showed a reduction range of $20-35 \%$. While the parameters color, oils, and total solids showed a more expressive reduction with the range of $45-63 \%$.

The presence of chloride in the dairy wastewater samples is mainly because chloride is present in the cleaning steps of reactors in the dairy industry. Its removal is then expressive 


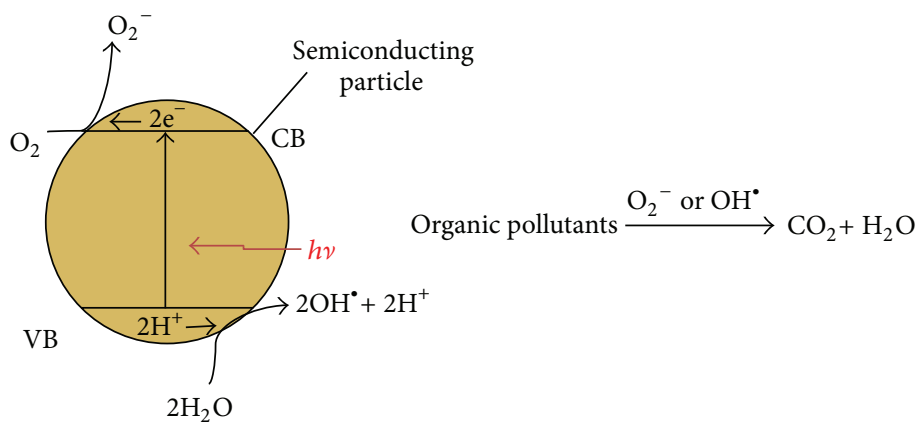

FIGURE 2: Schematic illustration of the UV-induced degradation of organic pollutants by semiconductors [9].

TABLE 2: Physical-chemical results for dairy effluent before and after AOP treatment.

\begin{tabular}{lccc}
\hline \multirow{2}{*}{ Parameters } & \multicolumn{2}{c}{ Results } & \multirow{2}{*}{ Percentage } \\
& in natura & After AOP & \\
\hline BOD $_{5}\left(\mathrm{mg} \mathrm{L}^{-1}\right)$ & 2218.7 & 1775 & 20 \\
Chloride $\left(\mathrm{mg} \mathrm{L}^{-1}\right)$ & 793.5 & 526 & 33.7 \\
Color $\left(\mathrm{Pt} \mathrm{Co}^{2}\right.$ & 6523.5 & 3260 & 50 \\
$\mathrm{~N}_{\mathrm{NH}}\left(\mathrm{mg} \mathrm{L}^{-1}\right)$ & 158.4 & 126.7 & 20 \\
Oil and grease $\left(\mathrm{mg} \mathrm{L}^{-1}\right)$ & 2002.1 & 750 & 62.5 \\
Phosphorus $\left(\mathrm{mg} \mathrm{L}^{-1}\right)$ & 208.5 & 156.4 & 25 \\
TOC $\left(\mathrm{mg} \mathrm{L}^{-1}\right)$ & 1010 & 690 & 31.7 \\
Total solids $\left(\mathrm{mg} \mathrm{L}^{-1}\right)$ & 10720 & 5886 & 45 \\
Turbidity $(\mathrm{NTU})$ & 2786 & 1894 & 32 \\
Zinc $\left(\mathrm{mg} \mathrm{L}^{-1}\right)$ & 5.0 & 5.0 & - \\
\hline
\end{tabular}

and could improve the biodegradability of the wastewater in a biological system.

The analysis of zinc before and after the treatment serves to verify the concentration of zinc as the process proceeds and shows the durability of the coated plate. No further studies were made to the coating plate in terms of longevity of the $\mathrm{ZnO}$ on the plate nor were biological studies conducted to verify the growth of any type of bacteria on the surface of the plate.

The results obtained indicate that the process is significantly more effective for the removal of color, oils, and solids. Thus, indications in this study show this process to be a valid pretreatment.

\subsection{Optimization of the Photocatalytic Process by Using the} Surface Response Methodology. Experiments were analyzed in terms of TOC effective percentage degradation as shown in Table 3.

Thus, the highest percentage of TOC degradation was of $31.6 \%$ for a $\mathrm{ZnO}$ coating thickness of $50 \mu \mathrm{m}$ and a $\mathrm{pH}$ of 8.0, corresponding to the central point of the matrix.

It is possible to visualize the optimized parameters when using a surface response methodology through a 3D graph. This is shown in Figure 3.

As it can be seen in Figure 3 (acquired by the software Minitab v. 15), surface maximum peak leans towards $\mathrm{pH} 8.0$
TABLE 3: Surface response methodology matrix using 2 factors and 15 runs in duplicate and TOC effective percentage degradation of the dairy effluent after the AOP treatment.

\begin{tabular}{|c|c|c|c|}
\hline Experiments & $\mathrm{pH}$ & $\begin{array}{l}\text { Thickness } \\
(\mu \mathrm{m})\end{array}$ & $\begin{array}{c}\text { TOC effective } \\
\text { percentage degradation }\end{array}$ \\
\hline 1 & 8.0 & 50 & 31.6 \\
\hline 2 & 10.0 & 100 & 5.4 \\
\hline 3 & 6.0 & 100 & 5.7 \\
\hline 4 & 6.0 & 0 & 7.9 \\
\hline 5 & 10.0 & 0 & 13.6 \\
\hline 6 & 10.0 & 0 & 6.8 \\
\hline 7 & 6.0 & 100 & 9.3 \\
\hline 8 & 6.0 & 0 & 1.3 \\
\hline 9 & 8.0 & 50 & 31.5 \\
\hline 10 & 10.0 & 100 & 10.6 \\
\hline 11 & 6.0 & 100 & 4.6 \\
\hline 12 & 6.0 & 0 & 0.5 \\
\hline 13 & 10.0 & 0 & 11.7 \\
\hline 14 & 10.0 & 100 & 7.5 \\
\hline 15 & 6.0 & 0 & 7.2 \\
\hline 16 & 10.0 & 100 & 13.6 \\
\hline 17 & 10.0 & 0 & 6.6 \\
\hline 18 & 8.0 & 50 & 26.4 \\
\hline 19 & 8.0 & 50 & 28.7 \\
\hline 20 & 6.0 & 100 & 5.4 \\
\hline 21 & 10.0 & 100 & 10.5 \\
\hline 22 & 8.0 & 50 & 26.6 \\
\hline 23 & 6.0 & 100 & 6.1 \\
\hline 24 & 6.0 & 0 & 2.4 \\
\hline 25 & 6.0 & 100 & 7.1 \\
\hline 26 & 8.0 & 50 & 25.9 \\
\hline 27 & 10.0 & 100 & 13.9 \\
\hline 28 & 10.0 & 0 & 4.4 \\
\hline 29 & 10.0 & 0 & 7.5 \\
\hline 30 & 6.0 & 0 & 4.4 \\
\hline
\end{tabular}

as its optimal variable. In terms of thickness, Figure 2 shows an increase as thickness is raised. Thus, a coating of $100 \mu \mathrm{m}$ seems to perform better results than a coating of $50 \mu \mathrm{m}$. This difference, however, is not as expressive as it is shown for $\mathrm{pH}$. This can be due to the relative small difference in thickness 


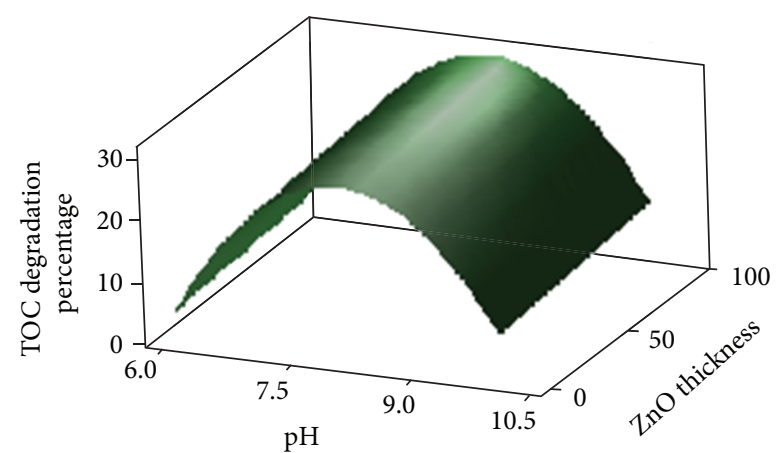

FIGURE 3: Surface Response graph in terms of TOC percentage removal by $\mathrm{ZnO}$ coating thickness and $\mathrm{pH}$.

TABLE 4: ANOVA of surface response methodology for the photocatalytic process of dairy wastewater.

\begin{tabular}{lcccc}
\hline & Coefficient & SE Coefficient & $t$-value & $P$ value \\
\hline Constant & 29.597 & 1.377 & 21.490 & 0.000 \\
$\mathrm{pH}$ & 1.798 & 0.746 & 2.409 & 0.025 \\
$\mathrm{ZnO}$ coating thickness & 1.283 & 0.746 & 1.719 & 0.100 \\
$\mathrm{pH} * \mathrm{pH}$ & -22.639 & 1.567 & -14.452 & 0.000 \\
$\mathrm{pH} *$ thickness & 0.072 & 0.746 & 0.097 & 0.924 \\
\hline
\end{tabular}

Where: $S=3.37352$, Rsq. $=91.08 \%$, Rsq.adj. $=89.45 \%$, Rsq.pred. $=86.73 \%$.

between both metal plates. The ANOVA of this methodology is shown in Table 4.

The model of this study can express $91 \%$ of TOC percentage degradation. Predicted value was $86.7 \%$ that corresponds to a difference of $5 \%$ from the model. The adjusted value was $89.5 \%$, and therefore it shows a difference of $1.8 \%$ from the model value. Thus, values were not parameterized, and the data included are significant.

Results showed that $\mathrm{pH}$ was significant $(P<0.05), \mathrm{ZnO}$ coating thickness was less significant in the process $(P=0.1)$, and the interaction of both variables was not significant $(P=$ $0.93)$.

After statistical analysis, the optimal conditions for the AOP using $\mathrm{ZnO}$ photoirradiated are $\mathrm{pH}$ 8.0, a value that was mentioned in [11], and $\mathrm{ZnO}$ coating thickness higher than $100 \mu \mathrm{m}$.

A new experiment was conducted with the optimized parameters from this study and the ones found in [10], that is, $\mathrm{pH}$ of $8.0, \mathrm{ZnO}$ coating thickness of $100 \mu \mathrm{m}$, reaction time of $3 \mathrm{~h}$, effluent concentration in natura, average radiation of $584.0 \mu \mathrm{W} / \mathrm{cm}^{2}$, reaction temperature of $31^{\circ} \mathrm{C}$, and average evaporation rate of $0.17 \mathrm{~L} / \mathrm{h}$. The TOC percentage removal was of $32 \%$ as obtained by $[8,12,13]$, though the authors employed $\mathrm{TiO}_{2}$ with lower organic load.

Something that must be taken into consideration is the cost of the process for $1 \mathrm{~h}$ of reaction. For this experiment, the cost of reagents is not high since there is only $\mathrm{pH}$ control during the whole process. $\mathrm{pH}$ values, however, tend to remain constant during the process once it is adjusted at the beginning of the process.
The energy source chosen for this study requires sun exposition only, preventing the use of lamps and hence minimizing the energy consumption of lamps.

There is no water consumption during the process because the effluent is directly treated; that is, no dilutions are required for the effluent of $1010 \mathrm{mg} \cdot \mathrm{L}^{-1}$ in this study.

\section{Conclusion}

Optimal values of the variables were $\mathrm{pH} 8.0$ and a $\mathrm{ZnO}$ coating thickness plate of $100 \mu \mathrm{m}$. When optimized, an effective TOC degradation of $31.7 \%$ was obtained.

Since solar/UV is a constant and free energy source in most tropical countries, this process suggests an elevated potential contribution to dairy wastewater treatment, especially as a pretreatment.

Subsequent studies may explore and enhance solar/UV collecting and diminished vaporization. Results from this study show that the photocatalytic degradation contributes to the organic load removal of effluents, and studies related to economic viability may expand the process.

In addition, nanometric $\mathrm{ZnO}$ can be used not only for dairy wastewater treatment but also for other types of industrial wastewater even to a scale-up level. There was 50\% of color removal in the dairy effluent, which can also be used in the treatment of dye industry effluents.

The AOP using $\mathrm{ZnO}$ photoirradiated can be associated with membranes and be an instrument in $\mathrm{H}_{2} \mathrm{O}$ treatment for industries' own water reuse, especially those like dairy industries in which water consumption is extremely high.

\section{Conflict of Interests}

The authors declare that there is no conflict of interests regarding the publication of this paper.

\section{Acknowledgments}

The authors thank Cooperativa de Laticinios de Guaratingueta, in the state of Sao Paulo (CLG), for the dairy wastewater sample used in this work. The authors also thank Marco Fernandes from DuPont for preparing the $\mathrm{ZnO}$-coated plates and Dr. Messias Borges Silva from the University of Sao Paulo.

\section{References}

[1] A. A. Khodja, T. Sehili, J.-F. Pilichowski, and P. Boule, "Photocatalytic degradation of 2-phenylphenol on $\mathrm{TiO}_{2}$ and $\mathrm{ZnO}$ in aqueous suspensions," Journal of Photochemistry and Photobiology A, vol. 141, no. 2-3, pp. 231-239, 2001.

[2] N. Daneshvar, D. Salari, and A. R. Khataee, "Photocatalytic degradation of azo dye acid red 14 in water on $\mathrm{ZnO}$ as an alternative catalyst to $\mathrm{TiO}_{2}$," Journal of Photochemistry and Photobiology A, vol. 162, no. 2-3, pp. 317-322, 2004.

[3] M. A. Behnajady, N. Modirshahla, and R. Hamzavi, "Kinetic study on photocatalytic degradation of C.I. Acid Yellow 23 by ZnO photocatalyst," Journal of Hazardous Materials, vol. 133, no. 1-3, pp. 226-232, 2006. 
[4] R. E. Bruns, I. S. Scarminio, and B. B. Neto, Como Fazer Experimentos, Editora Unicampo, Campinas, Brazil, 2003.

[5] B. Sarkar, P. P. Chakrabarti, A. Vijaykumar, and V. Kale, "Wastewater treatment in dairy industries-possibility of reuse," Desalination, vol. 195, no. 1-3, pp. 141-152, 2006.

[6] S. Göblös, P. Portöro, D. Bordás, M. Kálmán, and I. Kiss, "Comparison of the effectivities of two-phase and single-phase anaerobic sequencing batch reactors during dairy wastewater treatment," Renewable Energy, vol. 33, no. 5, pp. 960-965, 2008.

[7] W. Janczukowicz, M. Zieliński, and M. Debowski, "Biodegradability evaluation of dairy effluents originated in selected sections of dairy production," Bioresource Technology, vol. 99, no. 10, pp. 4199-4205, 2008.

[8] J. S. Carrocci, R. Y. Mori, O. L. C. Guimaraes et al., "Application of heterogenous catalysis with $\mathrm{TiO}_{2}$ photo irradiated by sunlight and latter activated sludge system for the reduction of vinasse organic load," Engineering, vol. 4, pp. 746-760, 2012.

[9] K. S. Choi, Band Gap Tuning of Zinc Oxide Films For Solar Energy Conversion, A CASPiE Module, Purdue University, West Lafayette, Ind, USA, 2007, http://papadantonakis. .com/images/9/91/Band_Gap_Module.pdf.

[10] G. R. L. Samanamud, C. C. A. Loures, A. L. Souza et al., "Heterogeneous photocatalytic degradation of dairy wastewater using immobilized ZnO," ISRN Chemical Engineering, vol. 2012, pp. 1-8, 2012.

[11] N. Daneshvar, M. H. Rasoulifard, A. R. Khataee, and F. Hosseinzadeh, "Removal of C.I. Acid Orange 7 from aqueous solution by UV irradiation in the presence of $\mathrm{ZnO}$ nanopowder," Journal of Hazardous Materials, vol. 143, no. 1-2, pp. 95-101, 2007.

[12] S. Malato, J. Blanco, D. C. Alarcón, M. I. Maldonado, P. Fernández-Ibáñez, and W. Gernjak, "Photocatalytic decontamination and disinfection of water with solar collectors," Catalysis Today, vol. 122, no. 1-2, pp. 137-149, 2007.

[13] R. F. S. Salazar, J. S. Carrocci, and H. J. I. Filho, "Employment of factorial design to evaluate the organic loading and aeration of biological systems in the degradation of dairy wastewater," Ambiente \& Água, vol. 6, no. 3, pp. 98-109, 2011. 

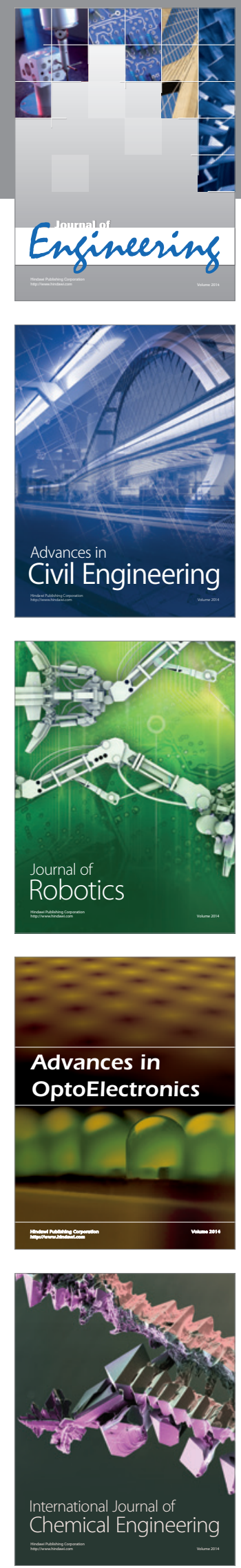

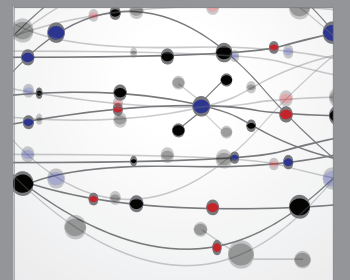

The Scientific World Journal
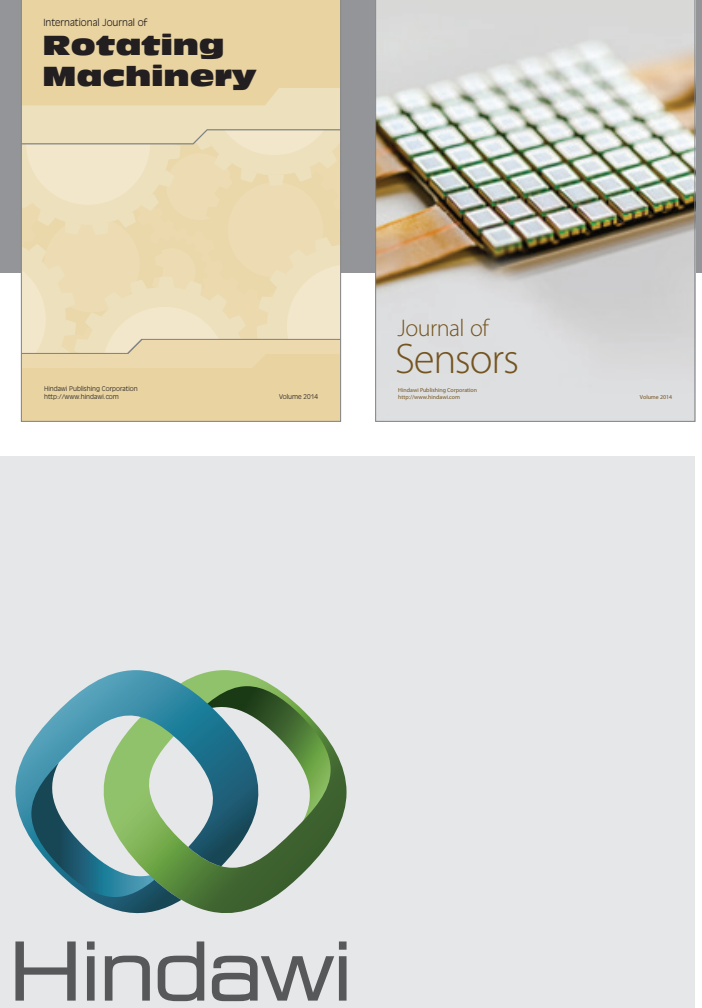

Submit your manuscripts at http://www.hindawi.com
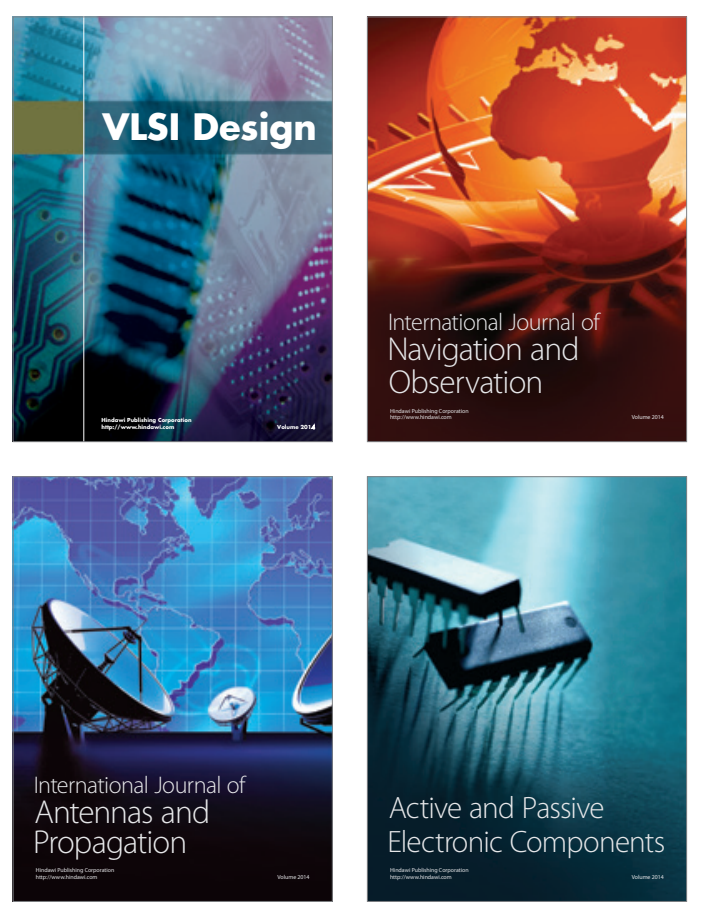
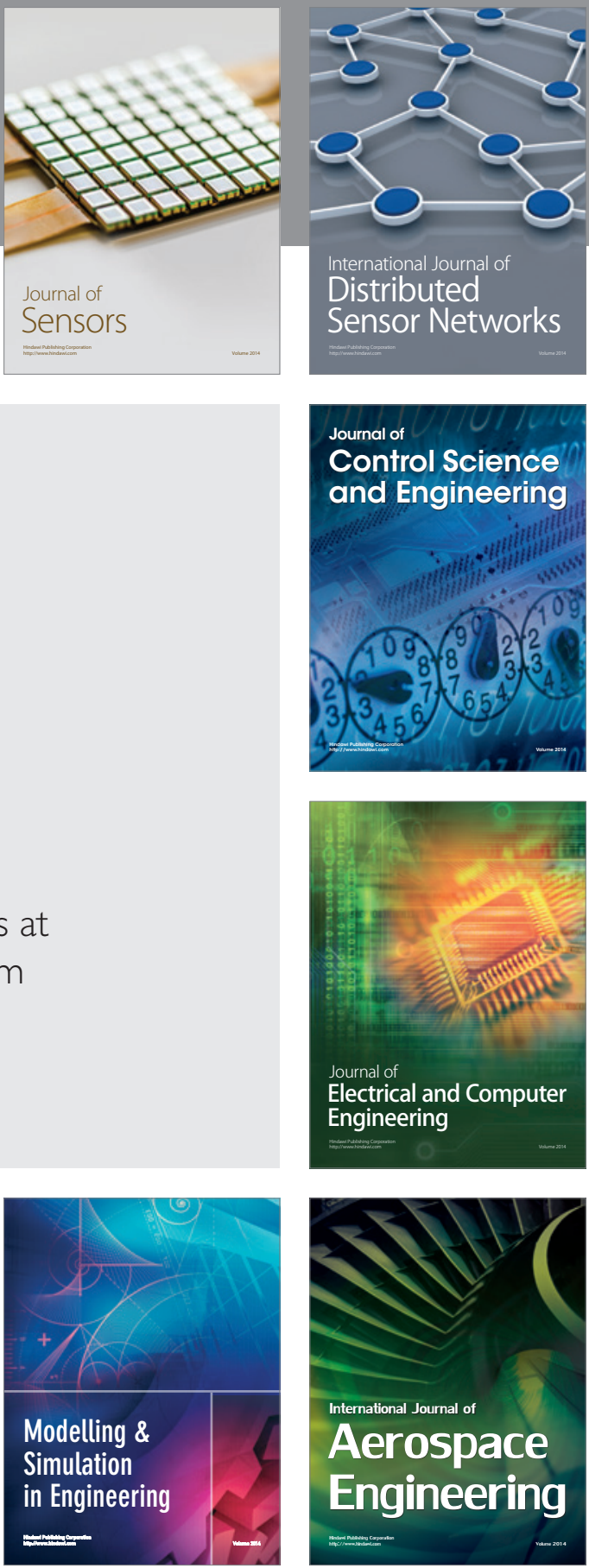

Journal of

Control Science

and Engineering
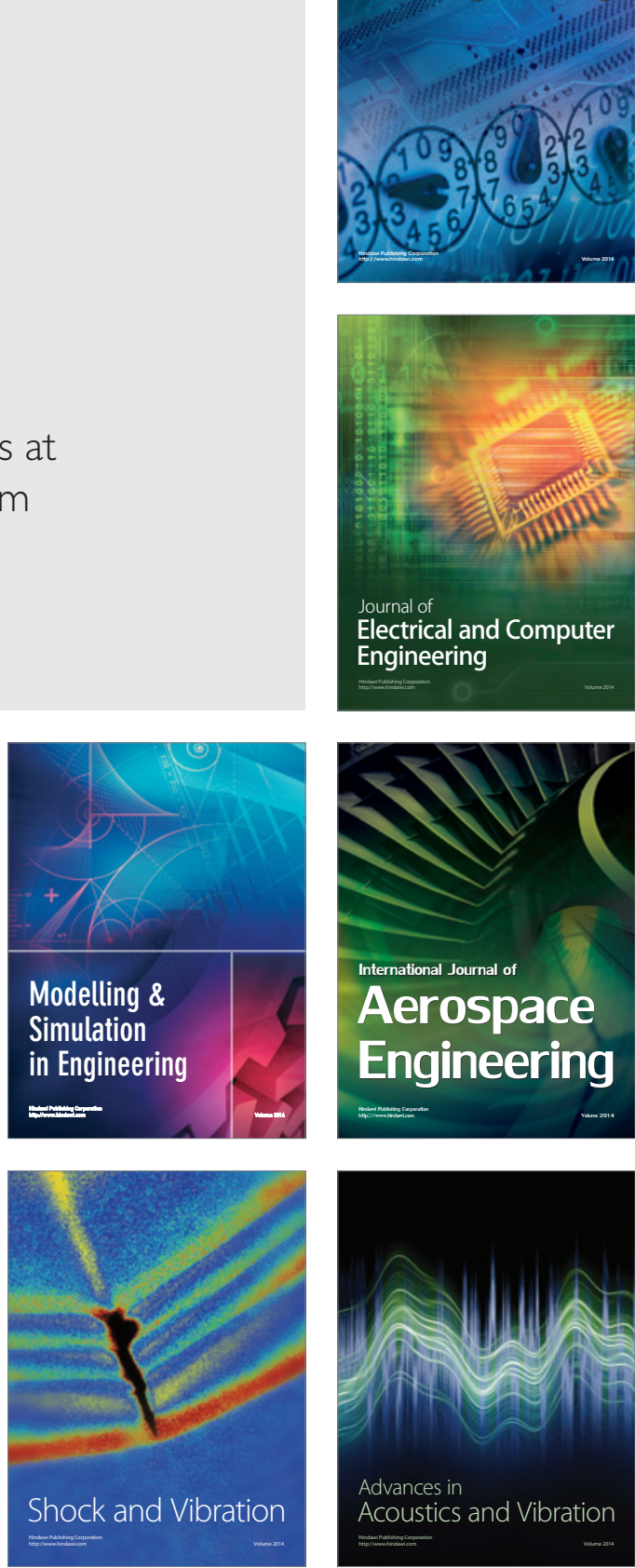